\title{
VALUATION OF PROPERTIES IN CLOSE PROXIMITY TO WASTE DUMPS SITES: THE NIGERIA EXPERIENCE
}

\author{
Victoria Amietsenwu BELLO ${ }^{1}$ and Mustapha Oyewole BELLO ${ }^{2} \bowtie$ \\ 1 Department of Estate Management, Federal University of Technology, Akure, Nigeria \\ E-mail: vicbellofuta@yahoo.com \\ ${ }^{2}$ Department of Estate Management, Federal University of Technology, Akure, Nigeria \\ E-mail: oyewolebello@yahoo.com
}

Received 4 August 2009; accepted 28 September 2009

\begin{abstract}
The paper identified and evaluated the techniques used by Nigerian Estate Surveyors and Valuers in valuing properties close to waste dump sites. A random sample of 107 Estate Surveyors and Valuers were taken from a sampling frame of 228 for the administration of questionnaire out of which 99 were returned. The data was analysed using the percentile, mean score and One Sample $t$-test. The results show that majority of the Estate Surveyors and Valuers were not aware of the existence of methodologies used for the valuation of environmentally contaminated properties. The result further showed that the Estate Surveyors and Valuers over value properties in close proximity to the waste dump sites using inappropriate methods. In view of these findings, the undergraduate and post-graduate curricula in Estate Management in the tertiary institutions should be reviewed to incorporate the appropriate methods of valuation in use for environmentally contaminated properties and the Continuous Professional Development (CPD) programme for the practitioners should be tailored to addresses this area of deficiency.
\end{abstract}

KEYWORDS: Valuation; Properties and Waste dump site

\section{INTRODUCTION}

The assessment of a property usually depends on the property's unique characteristics, each of which provides utilities or disutility to individuals. These characteristics are generally classified into those which are external and those that are internal to the property (Mackmin, 1985). External influences relate to the general state of the economy, population, employment, immigration, finance, location, transportation and environmental attributes, while the internal influences essentially constitute the specific details of the property such as size, accommodation, condition, design, layout, age, type and plot size (Adair et al., 1996; Bello, 2000). These value determining factors can be attributable to the nature of property as a package of goods and services (Bello and Bello, 2008). Therefore, property extends beyond shelter (the physical attributes of a property) to include environmental characteristics or attributes which refers to the quality of the neighborhood and location within the neighborhood. Environmental characteristics are manifested in the form of pull and push effect of the neighbourhood. The push effects could be characterized by proliferation of squatter 
settlements, air and water pollution, squalid condition of environmental sanitation, and breakdown of waste disposal arrangement (Bello and Bello, 2008) while the pull effect could be good roads, schools etc. When properties are in close proximity to environmental factors which could lead to push effects like waste dump sites, they demand special assessment on the part of the Estate Surveyors and Valuers. The question therefore, is what techniques do the Nigerian Valuers adopt in valuing properties close to waste dump sites? Are the techniques different from those used in properties not close to dump site or any environmental hazards?

The remainder of the paper is organized as follows. The next section (section 2) deals with previous research on the subject matter. Section (3) three presents a description of the methodology employed for the study, while section (4) four focuses on the empirical results. The concluding remarks and policy implication are contained in section (5) five.

\section{REVIEW OF PREVIOUS LITERATURE}

The pricing of properties close to waste dump sites have been studied extensively since the early 1980s using variety of methods (Lizieri et al., 1995). The methods range from the traditional market Comparison Approaches, the direct application of Cost through Yield Decomposition Techniques to Explicit Discounted Cash Flow Scenario Modeling Approach. In Nigeria, the traditional Valuation methodologies are used for pricing properties. The methods ranged from the Direct Comparison Method, the Cost Method to the Income Approach (Ogunba, 1997; Ogunba et al., 2005).

The Direct Capital Comparison Method allows valuers to analyze specifically the results of buyers and sellers interaction and to use market evidence (Sale price) to value other properties. While the method may be appro- priate in assessing the value of property under normal circumstances, it however, presents some difficulties with respect to valuation of properties close to waste dump sites, as Pederson (2002) noted that it would be difficult to make a meaningful comparative analysis since contamination can be specific to a property.

The Cost Method on its own is based upon the premise that the value of property is approximated by the investment necessary to replace that property (Acks, 1995). Replacement Cost typically includes land acquisition, the cost of site and building improvements, and an allowance for the developers' profit, less accrued depreciation (Acks, 1995). Wilson (1994) offered a cost based methodology for estimating the effects of waste (contamination) on value. He stressed that the estimation of the value of properties contaminated by waste must consider the "negative impact of intangible factors." Among these factors are the general demand for the subject in the market place, the level of confidence in remediation and its cleaning, the availability of financing for the contaminated property and the possibility of third-party liabilities. In Wilson's framework, the quantified effect of these intangible factors is deducted from an unimpaired value together with remediation costs and any quantifiable effect of use restrictions. In spite of Wilson (1994) argument in favour of Cost Method, Marchitelli (1992) questioned the use of the method and suggested that the method should be abandoned in the valuation process in most situations. This is because depreciation, which is one of the components used in Cost Method, is difficult to measure especially when the property is close to environmental hazards (waste dump sites in this case). If therefore, depreciation is to be accounted for explicitly, it must be on a realistic basis. To argue that depreciation has been taken into account by an implied means as in a "traditional" valuation, when there is no consensus as to the correct methods or amount is farcical. 
The Income Approach is based on the principle that annual values and capital values are related to each other and that given the income a property produces or its annual value, the capital value can be found (Kinnard, 1970; Millington 1990 and Baum et al., 1997). Variants of this method have been developed over the years, as Real Value Approach propounded by Wood (1972), which has been amended and reconciled with the Equated Yield Approach to produce a Real Value/Equated Yield Hybrid by Crosby (1985 and 1991). Also, included in the model are the Rational Approach based on the earlier work of Greaves (1972), and further developed by Sykes (1984) and the Discounted Cash Flow Technique etc. These techniques (variants of income approach) incorporate yearby-year projections of income and expenses and discounts the cash flows by an appropriate rate, and add the present value of the property at some future date. The methodology is amicable to income streams that do not conform to a pattern. When used for contaminated properties, the cost of remediation is central. For instance, Mundy (1992a) and Chalmers and Roehr (1993) opted for a Discounted Cash Flow Technique with multiple discount rates corresponding to the contamination related stigma risk for each year of the presumed holding period. The underlying concept echoes the comments of Patchin (1994) and Mundy (1992b) in that risk is not constant over the holding period. Indeed the authors suggested that the effect of stigma and its risk premium may decline over the holding period and subsequent to remediation. Furthermore, Neustein (1992) demonstrated a technique whereby simple income ratio can be used in a direct capitalization formula rather than actual difference in net operating income. This allowed Neustein (1992) to make a graduated set of comparisons of different capitalization rate premium and income ratios in terms of their effect on value. This simplifies the problem, but may not allow for final adjustments based on other variables.
In spite of these approaches, several analytical approaches are currently being used to measure environmental externalities and the extent to which they are internalized into real estate values (Furby et al., 1988). Well known to property appraisers are the Paired Sales Analysis used by Jackson (2001), Contingent Valuation Analysis (CVA) used by Carson, (2000); Clinch and Murphy, (2001), Option Pricing Model by Lentz and Tse (1995) and the Hedonic Model developed by Rosen (1974). These techniques have been used to estimate the benefits of things such as increased air and water quality as a result of contaminants like waste, increased risk from drinking water and groundwater contaminants, outdoor recreation, and protecting wetlands, wilderness areas and endangered species on property values at one point or the other (Carson, 2000; Clinch and Murphy, 2001). However, some of these techniques have been criticized by property valuation experts. For instance Des Rosiers et al. (1999) noted that the Paired Sales Analysis is somewhat speculative because the inherent heterogeneity of property market makes it difficult to isolate the price impact of a particular attribute. In this regard, Lancaster (1966), Rosen (1974), Damodaran (2006) and Des Rosiers and Theriault (2006) noted that the Hedonic Approach remains the most reliable and acceptable tool for valuing properties that are affected by environmental externalities as it reveals buyers perceptions of any potential environmental hazard through their actual pricing behaviour. Hedonic Model is a statistical technique used to isolate the effect and contribution of various housing attributes to real estate prices (Rosen, 1974). However, Rosen (1974) approach has been applied to a wide range of discipline among which are housing and environmental economics (Bajari and Kahn, 2005). In the hedonic model, a house is seen as a bundle of characteristics, and its price is given as a function of those characteristics. Homebuyers maximize their utility by 
purchasing the house that falls within their budget and contains the most characteristics in monetary terms (Vanderford et al., 2005). Theoretically, a homebuyer purchases a set of characteristics, not a house per say. Hence it's growing popularity among urban economist and property appraisers (Des Rosiers et al., 1999). The hedonic technique has been used in numerous studies to determine the effects of various characteristics on house prices and to compare the prices of homes that differ on key characteristics. The value that a characteristic adds to the price of a house can be thought of as an implicit price - the expected benefits over time - for the characteristic, where it is assumed that the expected benefits of a given characteristic are the same for all potential consumers (Vanderford et al., 2005). Such implicit price determination is particularly helpful for characteristics that are not priced independently, as is the case for most housing characteristics.

The general consensus in the literature is that the traditional method of valuation is inadequate in the valuation of environmentally contaminated property. With this in view, the study identified and evaluated the predominant methods in use among Nigerian practitioners.

\section{DATA AND METHODOLOGY EMPLOYED}

The target population for the study is the registered Estate Surveyors and Valuers in Lagos whose names are contained in an updated 2002 Directory published by the Estate Surveyors and Valuers Registration Board of Nigeria (ESVRBON). The total number of registered practicing Estate Surveyors and Valuers whose names are in the directory are 228 of which a sample size of 107 was chosen using the simple random technique. 107 Questionnaires were administered on these Estate Surveyors and Valuers out of which 99 were filled and returned for analysis using percentiles and mean score.

Using the methodology of Finlay and Tyler (1991) and Bello (2002) the respondents were asked of their awareness, usage and understanding of the methods of valuation used in practice.

In evaluating the techniques used in valuing contaminated properties, the fifty one (51) Estate Surveyors and Valuers (those who are registered) were engaged to value eight recently sold properties, two located in close proximity to each of the waste dump site at Olusosun, Solous and Abule-Egba respectively and the other two located at Ketu where there is no identifiable waste dump site in sight. Their valuations were compared with the actual sales price of the properties. The dispersion between these valuations and the sales price were analyzed and tested using $t$ - statistic.

\section{EMPIRICAL ANALYSIS AND DISCUSSION OF RESULTS}

Tables 1 and 2 show the qualification and status of the respondents. In Table 1, 51 out of the 99 respondents are registered or deemed to be registered Estate Surveyors and Valuers. This category was considered for further analysis. This was to ensure that the views of only those qualified to assess property values according to Decree No 24 of 1975 were considered.

Also, the survey according to Table 2 shows that over 70 percent of the respondents held key position in their respective organisations. This lays credence to the information collected for this analysis.

Table 3 shows that majority of the Estate Surveyors and Valuers have heard, used and understood mainly the five traditional methods (Comparative, Cost, Investment, Residual and Profit) of valuation. Although, 52.94 percent of the Estate Surveyors and Valuers have heard of the Discounted Cashflow Techniques, only 
Table 1. Distribution of respondents according to qualification

\begin{tabular}{lll}
\hline Qualification & No of respondents & Percentage no of respondents \\
\hline HND only & 14 & 14.14 \\
B.SC only & 29 & 29.30 \\
B.SC/ HND with ANIVS/Fellow* & 44 & 44.44 \\
M.SC with ANIVS* & 7 & 7.07 \\
Others & 5 & 5.05 \\
Total & 99 & 100 \\
\hline
\end{tabular}

Source: Field data (2008)

* Registered Estate Surveyors and Valuers $(44+7=51)$

Table 2. Distribution of respondents according to status

\begin{tabular}{lll}
\hline Status & No of respondents & Percentage no of respondents \\
\hline Principal partners & 22 & 22.22 \\
Branch managers & 16 & 16.16 \\
Senior estate surveyors and valuers & 42 & 42.42 \\
Estate surveyors and valuers & 15 & 15.15 \\
Others & 4 & 4.05 \\
Total & 99 & 100 \\
\hline
\end{tabular}

Source: Field data (2008)

Table 3. Awareness of the specific techniques of valuing contaminated properties

\begin{tabular}{|c|c|c|c|c|c|c|}
\hline \multirow[t]{2}{*}{ Techniques } & \multicolumn{2}{|c|}{$\begin{array}{l}\text { Awareness of } \\
\text { methodology }\end{array}$} & \multicolumn{2}{|c|}{$\begin{array}{l}\text { Usage of } \\
\text { methodology }\end{array}$} & \multicolumn{2}{|c|}{$\begin{array}{l}\text { Understanding of } \\
\text { methodology }\end{array}$} \\
\hline & No & Percentage & No & Percentage & No & Percentage \\
\hline Paired sales Analysis & 6 & 11.76 & 1 & 1.96 & 3 & 5.88 \\
\hline Contingent Valuation Analysis (CVA) & 5 & 9.80 & 0 & 0.00 & 3 & 5.88 \\
\hline Option Pricing Model & 6 & 11.76 & 4 & 7.84 & 5 & 9.80 \\
\hline Discounted Cash Flow Techniques & 27 & 52.94 & 14 & 27.45 & 18 & 35.29 \\
\hline Hedonic approach & 10 & 19.61 & 0 & 0.00 & 1 & 1.96 \\
\hline Comparative method & 51 & 100 & 51 & 100 & 51 & 100 \\
\hline Cost method & 51 & 100 & 51 & 100 & 51 & 100 \\
\hline Investment method & 51 & 100 & 47 & 92.16 & 51 & 100 \\
\hline Residual method & 51 & 100 & 28 & 54.90 & 30 & 58.82 \\
\hline Profit method & 51 & 100 & 15 & 29.41 & 38 & 74.51 \\
\hline
\end{tabular}

Source: Field data (2008)

27.45 have actually used the method. Also, other available techniques are the Paired Sales Analysis, the Contingent Valuation Analysis, Option Pricing Model and the Hedonic Model. For the Paired Sales Analysis and the Option
Pricing Model, 11.76 percent of the Estate Surveyors and Valuers have heard of the methodology respectively. 1.96 percent of the Estate Surveyors and Valuers have actually used the Paired Sales Analysis while 7.84 percent of the 
Valuers have used the Option Pricing Model. Also, 9.80 percent and 19.61 percent of the Estate Surveyors and Valuers have heard of the Contingent Valuation Analysis (CVA) and Hedonic Model respectively while none of the Estate Surveyors and Valuers has used the Methodologies.

Table 4 shows Comparative Method as the most frequently used techniques by the respondents (mean rating 3.81). This is followed by Cost method with mean rating of 3.70 ; Investment Method with mean rating of 3.35 .
These three methods are the methods the Estate Surveyors and Valuers normally used in the valuation of properties not contaminated. The question is whether they use these methods in the manner that will reflect the effect of contamination on the affected properties.

Table 5 gives the description of the properties that were recently sold in the four neighbourhoods (Olusosun, Solous, Abule - Egba and Ketu). These were the properties the Valuers were engaged to value without disclosing their sales price to them.

Table 4. Methods used in the valuation of properties that are contaminated by waste dump sites

\begin{tabular}{lllllll}
\hline Methods & \multicolumn{2}{l}{ SCALE } & & & \\
\cline { 2 - 6 } & 1 & 2 & 3 & 4 & Mean score & Ranking \\
\hline Pared sales Analysis & 97.3 & 2.70 & 0.00 & 0.00 & 1.02 & 8 \\
Contingent Valuation Analysis (CVA) & 100 & 0.00 & 0.00 & 0.00 & 1.00 & 9 \\
Option Pricing Model & 89.20 & 8.10 & 2.70 & 0.00 & 1.13 & 7 \\
Discounted Cash Flow Techniques & 19.00 & 27.00 & 24.30 & 29.70 & 2.64 & 4 \\
Hedonic Approach & 100 & 0.00 & 0.00 & 0.00 & 1.00 & 10 \\
Comparative method & 0.00 & 0.00 & 18.90 & 81.10 & 3.81 & 1 \\
Cost method & 0.00 & 5.40 & 18.90 & 75.70 & 3.70 & 2 \\
Investment method & 0.00 & 18.90 & 27.00 & 54.10 & 3.35 & 3 \\
Residual method & 81.10 & 5.40 & 5.40 & 8.10 & 1.40 & 5 \\
Profit method & 78.40 & 10.80 & 5.40 & 5.40 & 1.37 & 6 \\
\hline
\end{tabular}

Source: Field data (2008)

Table 5. Description of property

\begin{tabular}{llll}
\hline Property type & Description & Location & Sales price \\
\hline A & 14 rooms tenement building & Olusosun & 5400000 \\
B & 3 bedroom detached house & Olusosun & 8500000 \\
C & 13 rooms tenement building & Solous & 5800000 \\
D & 3 bedroom detached house & Solous & 9800000 \\
E & 10 rooms tenement building & Abule - Egba & 6000000 \\
F & 3 bedroom detached house & Abule - Egba & 12000000 \\
G & 12 rooms tenement building & Ketu & 5800000 \\
H & 3 bedroom detached house & Ketu & 9000000 \\
\hline
\end{tabular}

Source: Field data (2008) 
Table 6. One sample $t$ - test

\begin{tabular}{llllllll}
\hline $\begin{array}{l}\text { Property } \\
\text { type }\end{array}$ & $\begin{array}{l}\text { Test value } \\
\text { (Sales price) }\end{array}$ & T & Df & Sig $(2-$ tailed) & Mean diff & \multicolumn{2}{c}{ 95\% Confidence interval } \\
\hline A & 5400000 & 8.26 & 50 & .000 & & Upper limit & Lower limit \\
B & 8500000 & 9.43 & 50 & .000 & 628431.37 & 626980.60 & 1029882 \\
C & 5800000 & 7.09 & 50 & .000 & 676470.59 & 532883.30 & 820057.90 \\
D & 9800000 & 5.05 & 50 & .000 & 631372.55 & 595823.60 & 1066922 \\
E & 6000000 & 8.15 & 50 & .000 & 7470533.33 & 381289.90 & 885376.70 \\
F & 12000000 & 7.08 & 50 & .000 & 563027 & 931090.70 \\
G & 5800000 & 0.89 & 50 & 0.377 & 652941.18 & 467795.10 & 838087.30 \\
H & 9000000 & 0.55 & 50 & 0.585 & 98039.22 & -122955 & 319033.70 \\
\hline
\end{tabular}

Source: Field data (2008)

Table 6 shows one sample $t$ - test for the valuation of the 51 Estate Surveyors and Valuers together with their Sales Prices. This procedure tests whether the mean of the valuation figures estimated by the Estate Surveyors and Valuers for each of the property differs from the Sales Price of the property (i.e. Valuation Accuracy).

For properties located in Olusosun (property $\mathrm{A}$ and B), Solous (property C and D) and Abule - Egba (property E and F), they have their confidence intervals entirely above 0.00 , which implies that the Estate Surveyors and Valuers produce valuation figures that are significantly higher than the sales price, while this is not so for the two properties in Ketu (property G and $\mathrm{H})$. The results obviously come from the fact that none of the Estate Surveyors and Valuers took the effect of the waste dump site on the properties into consideration, hence they tend to over value the properties in close proximity to the waste dump sites.

\section{CONCLUSION AND POLICY IMPLICATION}

It is evident from this study that the Estate Surveyors and Valuers are not aware and do not understand the techniques of valuation that has been developed for the valuation of properties that are contaminated especially by waste. The few of the techniques they are aware of and understood are the traditional valuation techniques commonly used in practice whose reliability has been questioned by valuation experts.

It is therefore, not uncommon that the inability of the majority of the Estate Surveyors and Valuers to understand the theoretical basis underlying these techniques stems from the nature and content of their undergraduate curricula. In this wise, the undergraduate curriculum should be broadened and extended beyond the confines of the traditional Methods of valuation. Those in academics should also brace up to the challenges in keeping themselves abreast with what obtains in the world in the field of valuation as the world is fast becoming a global village.

The Nigerian Institution of Estate Surveyors and Valuers should not be left out of this. The Institution should make sure that the Continuous Professional Development (CPD) programme addresses this area of deficiency. This will help to enlighten the practicing Estate Surveyors and Valuers who are ignorant of most of the available techniques in carrying out valuation of contaminated properties. 


\section{REFERENCES}

Acks, K. (1995) Valuation of Environmental Damages to Real Estate. [Online] Environmental Valuation \& Cost Benefit Group. Available at: http://www.costbenefitgroup.com/text/html/ valredi4.htm

Adair, A., Berry, J. and McGreal, S. (1996) Valuation of residential property: analysis of participant behaviour, Journal of Property Valuation and Investment, 14(1), pp. 20-35. doi:10.1108/14635789610107453

Bajari, P. and Kahn, M. (2005) Estimating housing demand with an application to explaining racial segregation in cities, Journal of Business \& Economic Statistics, 23(1), pp. 20-33. doi:10.1198/073500104000000334

Baum, A.E., Mackmin, D. and Nunnington, N. (1997) Income Approach to Property Valuation. London: International Thompson Business Press.

Bello, O.M. (2002) A study on the residential property investment performance and its measurement in Lagos metropolis. A PhD thesis submitted to the Department of Estate Management, Federal University of Technology, Akure.

Bello, M.O. and Bello, V.A. (2008) Willingness to pay for better environmental services: evidence from the Nigerian real estate market, Journal of African Real Estate Research, 1(1), pp. 19-27.

Bello, V.A. (2000) An empirical analysis of the determinants of residential property values in Lagos metropolis. M.Tech thesis, Department of Estate Management, Federal University of Technology, Akure.

Carson, R.T. (2000) Contingent valuation: A users guide, Environmental Science \& Technology, 34(8), pp. 1413-1418. doi:10.1021/es990728j

Chalmers, J.A., and Roehr, S.A. (1993) Issue in the valuation of contaminated property, The Appraisal Journal, 61(1), pp. 28-40.

Clinch, J. and Murphy, A. (2001) Modeling winners and losers in contingent valuation of public goods: appropriate welfare measures and econometric analysis, Economic Journal, 111(470), pp. 420-443. doi:10.1111/1468-0297.00614

Crosby, N. (1985) The Application of Equated Yield and Real Value Approaches to the Market Valuation of Commercial Property Investment. PhD thesis, University of Reading.

Crosby, N. (1991) The practice of property investment appraisal: reversionary freeholds in the UK, Journal of Property Valuation and Investment, 9(2), pp. 109-122. doi:10.1108/14635789110030840
Damodaran, A. (2006) Valuation approaches and metrics: A survey of the theory and evidence. [Online] Stern School of Business. Available at: http://pages.stern.nyu.edu/ adamodar/pdfiles/ papers/valuesurvey.pdf

Des Rosiers, F., Bolduc, A. and Theriault, M. (1999) Environment and value: Does drinking water quality affect house prices? Journal of Property Investment and Finance, 17(5), pp. 444-463. doi:10.1108/14635789910294877

Des Rosiers, F. and Theriault, M. (2006) Mass appraisal, hedonic price modelling and urban externalities: understanding property value shaping processes. [Online] Discussion Paper presented at the Advances in Mass Appraisal Methods Seminar, Delft University of Technology, October 30-31, 2006. Available at: http://www.tudelft.nl/live/binaries/ac23443b6d94-4513-a9ea-d312362c0b8b/doc/Paper\%20 Des\%20Rosiers\%20revised.pdf

Finlay, P.N. and Tyler, S.B. (1991) The performance measurement of property investment, Journal of Property Valuation and Investment, 9(4), pp. 295-312. doi:10.1108/14635789110030985

Furby, L., Slovic, P., Fischhoff, B. and Gregory, R. (1988) Public perception of electric power transmission lines, Journal of Environmental Psychology, 8, pp. 19-43. doi:10.1016/S0272-4944(88)80021-5

Greaves, M.J. (1972) The investment method of property valuation and analysis: An examination of some of its problems. Ph.D thesis, University of Reading.

Jackson, T.O. (2001) The effects of previous environmental contamination on industrial real estate prices, The Appraisal Journal, 69(2), pp. 200-210.

Kinnard, W.N., Jr. (1970) Income Property Valuation. Lexington, MA: Health and Company.

Lancaster, K.J. (1966) A new approach to consumer theory, Journal of Political Economy, 74, pp. 132-156. doi:10.1086/259131

Lentz, G.H. and Tse, K.S.M. (1995) An option pricing approach to the valuation of real estate contaminated with hazardous materials, Journal of Real Estate Finance and Economics, 10(2), pp. 121-144. doi:10.1007/BF01096985

Lizieri, C., Palmer, S., Finlay, L. and Charlton, M. (1995) Valuation methodology and environmental legislation: A research project for the RICS Education Trust, City University Business School discussion paper series, City University: London.

Mackmin, D. (1985) Is there a residential valuer in the house? Journal of Property Valuation and 
Investment, 3(4), pp. 384-390. doi:10.1108/eb007982

Marchitelli, R. (1992) Rethinking the cost approach, The Appraisal Journal, 60(3), pp. 424-426.

Millington, A. (1990) An Introduction to Property Valuation. London: Estates Gazette.

Mundy, B. (1992a) The impact of hazardous materials on property value, The Appraisal Journal, 60(2), pp. 156-162.

Mundy, B. (1992b) Stigma and value, The Appraisal Journal, 60(1), pp. 7-13.

Neustein, R.A. (1992) Estimating value diminution by the income approach, The Appraisal Journal, 60(2), pp. 283-285.

Ogunba, O.A. (1997) A study of valuation and pricing practices in the residential property market in Lagos metropolis. M.Sc thesis, Obafemi Awolowo University, Ile-Ife.

Ogunba, O.A., Ajayi, C.A. and Aluko, B.T. (2005) Substitution versus anticipation: A resolution of the Nigerian valuation practice paradox, Journal of Land Use and Development Studies, 1(1), pp. 1-12.

Patchin, P. (1994) Contaminated properties and the sales comparison approach, The Appraisal Journal, 62(3), 402-409.
Pederson, P. (2002) Contaminated Property Appraisal: A Practical Guide to Minimizing Liability. Appraisal Institute of Canada Resource Center, pp. 1-17.

Rosen, S. (1974) Hedonic prices and implicit markets: product differentiation in pure competition, Journal of Political Economy, 82(1), pp. 34-55. doi:10.1086/260169

Sykes, S. (1984) Property valuation: A rational model, Journal of Property Valuation and Investment, 2(3), pp. 258-270. doi:10.1108/eb007956

The Estate Surveyors and Valuers Registration Board of Nigerian (2002) Membership Directo$r y$, Sixth Edition, Lagos, Donald Rowland's Ltd.

Vanderford, S.E., Mimura, Y. and Sweaney, A.L. (2005) A hedonic price comparison of manufactured and site-built homes in the Non-MSA U.S. Journal of Real Estate Research, 27(1), pp. 83-104.

Wilson, A. R. (1994) The environmental opinion basis for an impaired value opinion, The Appraisal Journal, 62(3), pp. 410-423.

Wood, E. (1972) Property investment - A real value approach. Ph.D thesis, University of Reading.

\section{SANTRAUKA}

\section{NETOLI SĄVARTYNŲ ESANČIO TURTO VERTINIMAS: NIGERIJOS PATIRTIS}

\section{Victoria Amietsenwu BELLO, Mustapha Oyewole BELLO}

Šiame darbe nustatyti ir ivertinti metodai, kuriuos taiko Nigerijos matininkai ir turto vertintojai, vertindami netoli sąvartynų esantị turtą. Iš ėmimo sąrašo su 228 galimais respondentais atsitiktine tvarka atrinkta 107 matininku ir turto vertintoju imtis, jiems itteiktos anketos, iš kuriu gražintos 99. Duomenys nagrinèti taikant procentili, vidutinị balą ir vienos imties t testą (angl. One Sample t-test). Rezultatai rodo, kad daugelis matininku ir nekilnojamojo turto vertintoju nežino apie metodikas, taikomas vertinant nuosavybę užterštoje aplinkoje. Be to, rezultatai rodo, kad matininkai ir turto vertintojai pervertina netoli sąvartynu esanti turta, taikydami netinkamus metodus. Atsižvelgiant $\mathfrak{z}$ šias išvadas, reikètu pakoreguoti nekilnojamojo turto valdymo studiju programas, skirtas pirmojo ir antrojo ciklo studentams aukštesniosiose ir aukštosiose mokyklose, itraukiant atitinkamus vertinimo metodus, taikomus vertinant nuosavybę užterštoje aplinkoje, o praktikams reikètų paruošti Nuolatinio profesinio ugdymo (CPD) programa, kuri padètų užpildyti šią spraga. 